\title{
FENOMENA PERTANIAN DI DESA CELUK BURUAN BALI DALAM MEDIA DOKUMENTER
}

\author{
I Nyoman Anom Fajaraditya Setiawan ${ }^{1}$, I Nyoman Widhi Adnyana², Putu Wirayudi Aditama ${ }^{3}$ \\ 1,2,3 STMIK STIKOM Indonesia \\ anomkojar@stiki-indonesia.ac.id ${ }^{1}$, manwidhi@stiki-indonesia.ac.id², \\ wirayudi.aditama@stiki-indonesia.ac.id ${ }^{3}$
}

\begin{abstract}
Abstrak
Pertanian sebagai salah satu sektor penting dalam pemenuhan kebutuhan pangan sebenarnya telah memiliki berbagai piranti hukum yang mendukung. Pesatnya pembangunan dan gencarnya pengadaan infrastruktur ternyata bertambah pesat pula alih fungsi lahan-lahan produktif milik petani. Fenomena ini diikuti pula dengan hasil panen dan industri kecil sebagai pendukung perputaran ekonomi kerakyatan yang perlahan mulai menurun. Perancangan dokumenter tentang eksistensi pertanian dan industri pertanian di Celuk Buruan dilakukan untuk membangkitkan kembali semangat agraris pada sektor ini. Pendekatan riset yang dilakukan dengan pengumpulan data secara kualitatif dari informan, perlahan diungkap fenomena pada realitasnya. Didukung proses perancangan dalam merealisasikan dokumenter, riset ini diharapkan dapat memberikan luaran yang semestinya menjadi bahan renungan khalayak. Tidak hanya termotivasi oleh tindakan penyelamatan sektor pertanian, namun mengingatkan kembali bahwa pertanian adalah salah satu garda terdepan dalam pemenuhan kebutuhan manusia terutama pada kondisi sulit saat ini. Media dokumenter ini dapat menjadi suatu edukasi untuk khalayak agar tidak memandang sektor pertanian dengan sebelah mata. Sehingga pada akhirnya perlu diambil tindakan dalam berbagai studi untuk mengkaji beragam hal terkait pertanian untuk strategi tindakan selanjutnya.
\end{abstract}

Kata Kunci: Bali, Celuk Buruan, dokumenter, pertanian

\begin{abstract}
Agriculture as one of the significant sectors within food commodity has had various supporting legal tools. The rapid development and incessant provision of infrastructure have also rapidly increased the conversion of productive land owned by farmers. This phenomenon followed by yields and the small industry as a supporter of the people's economy that slowly starts to decrease. The documentary design about the agriculture existence and the agricultural industrial sector in Celuk Buruan was carried to revive the spirit of agrarian in this sector. The research approach was performed by collecting data qualitatively from the informants. Slowly the phenomenon is revealed in its reality. Supported by the design process in realizing the documentary, this research is expected to be able to provide an outcome that should be the subject of public reflection. Not only motivated by the act of saving the agricultural sector but reminded that agriculture is one of the frontlines in fulfillment of human needs, especially under current difficult conditions. This documentary media can be an education for society in order not to demean the agricultural sector. Therefore, eventually, it is necessary to take action in various studies to examine multiple matters related to agriculture for further action strategies.
\end{abstract}

Keywords: agriculture, Bali, Celuk Buruan, documentary 


\section{PENDAHULUAN}

Budaya agraris sebagai akar budaya Indonesia memberikan dampak pada berbagai lini kehidupan masyarakat sejak lampau. Budaya ini kemudian berkembang menjadi budaya-budaya pada sub-sub lainnya yang merupakan struktur dari budaya komunal di negeri ini. Tidak hanya sampai pada pengembangan satu bidang saja, namun perkembangan tersebut menyentuh pula pada lini industri yakni industri pertanian dan kini bahkan masuk pada lini industri budaya pariwisata. Pertanian juga merupakan tulang punggung ekonomi pangan, menjadikan bidang pertanian suatu sandaran penting dari keberlangsungan kehidupan negeri ini.

Pertanian sebagai salah satu fondasi budaya agraris, perlu dilihat kembali keberlangsungannya pada saat ini atas pengaruh berbagai hal yang yang berkaitan dengan pembangunan (Metrobali.com, n.d.). Berbagai isu pengembangan dan hasil pada pertanian, misalnya swasembada pangan, pertanian terintegrasi, dan sebagainya, menjadi suatu wacana yang semestinya kembali untuk dipertimbangkan ke depan. Selain pengembangan pada komponen kesejatian pertanian, juga akan berdampak pada bidang lain seperti halnya pariwisata.

Pada sisi yang berbeda, pertanian justru mengalami perubahan sudut pandang, terutama kaitannya dengan lahan-lahan produktif. Berbagai hal yang terkait dengan fenomena ini selalu terselubung oleh tabir kemajuan pembangunan. Keadaan ini pun secara langsung mempengaruhi beragam varietas pertanian yang selama ini dianggap diunggulkan. Berkurangnya lahan produktif akhirnya tidak terelakkan, bahkan sampai pada pengaruhnya terhadap budaya yang telah berkembang dari fondasi kearifan agraris. Kejadian ini dirasa telah banyak terjadi di berbagai daerah, khususnya di Bali yang sebelumnya ekonomi digerakkan oleh pertanian dan kini digerakkan oleh sektor pariwisata. Selain permasalahan lahan, muncul pula keengganan generasi muda dalam menekuni bidang pertanian dan hal ini merubah pula sudut pandang yang ada terhadap lahan produktif tersebut menjadi aset yang berpeluang untuk dijual.

Dampak-dampak dalam fenomena pertanian, salah satunya terjadi di Desa Buruan, kecamatan Blahbatuh, Kabupaten Gianyar, Provinsi Bali. Daerah ini sebelumnya terbentang luas lahan persawahan yang kini semakin menyempit karena tuntutan kebutuhan dibalik pengembangan kawasan. Lahan pertanian yang sebelumnya menjadi tulang punggung masyarakat desa, kini menjadi hal yang dilematis untuk tetap dipertahankan karena berbagai faktor. Hingga kini, alih fungsi lahan menjadi momok yang selalu menghantui pada aktifitas pertanian di desa ini.

Perubahan kawasan yang kini menjadi sangat strategis oleh situasi, dengan dampingan akses fasilitas umum yang sangat mendukung menjadi polemik baru pada usaha disekitarnya. Bukan hanya berdampak pada lahan, petani dan hasil pertaniannya, tetapi juga pada industri pertanian yang sebenarnya turut mendukung ekonomi pertanian tersebut. Hasil panen yang tentunya menurun karena menyempitnya lahan pertanian, ancaman keberlanjutan industri kecil bidang pertanian ini pun akan ikut merasakan 
getahnya. Namun ironi ini tidak hanya sampai disana saja, muncul pula dampak pergeseran pada organisasi tradisional subak yang telah menjadi warisan budaya dunia.

Oleh sebab itulah dirasa akan menarik jika fenomena ini diangkat menjadi sebuah alur cerita sebagai bahan renungan untuk generasi muda dan generasi berikutnya. Bahwa kita semua harus memikirkan kembali sektor-sektor yang mulai ditinggalkan sebagai dasar fondasi pergerakan ekonomi kerakyatan. Fenomena ini pun akan disajikan dalam bentuk dokumenter agar alur cerita secara fakta lapangan muncul ke permukaan sebagai suatu jalur penyadaran akan pentingnya budaya pertanian. Pernyataanpernyataan dari para pelaku secara langsung tersaji tanpa ada rekaan akan menghidupkan nuansa dalam media panyampai pesan. Dokumenter ini diharapkan menjadi sebuah setapak untuk membangun kembali pertanian di benak generasi mendatang sebagai sebuah peluang tanpa harus sepenuhnya merubah makna filosofisnya. Selain menjadi bahan renungan, dokumenter ini pula disajikan berbeda dengan diangkatnya permasalahan antara tantangan petani dan tuntutan kemajuan dalam pembangunan.

Merujuk pada landasan teori, terkait tentang teori dan wacana film dan sinema yang akan menjadi dasar perancangan media yang akan dibuat. Prihal sinema memiliki turunan yang beragam diantaranya pada komponen video. Kata video berasal dari bahasa latin yang berarti saya lihat dan video adalah teknologi pemrosesan sinyal elektronik yang mewakilkan gambar yang bergerak, teknologi ini secara umum diterapkan pada televisi (Binanto, 2010). Istilah lain dalam penggunaan kata video juga digunakan sebagai singkatan videotape, perekam video, dan pemutar video (Binanto, 2010). Teknologi pemrosesan yang telah disebutkan tentunya akan berkaitan dengan luaran pada dokumenter yang dirancang.

Berkaitan dengan teori sebelumnya, video dapat diasumsikan sebagai perekaman dalam transmisi, frekuensi video yang dapat diterima pada televisi. Hal ini terkait pula dengan tindakan dokumentasi dalam bentuk video recording. Proses kerja dari video ini, selain sebagai dokumentasi juga dilakukan pada kebutuhan broadcasting (Setiawan, 2018). Tidak hanya itu, video memiliki ragam jenis genre dan salah satunya adalah dalam bentuk dokumenter. Dokumenter merupakan genre non-fiksi yang terfokus mengangkat dokumentasi aspek-aspek realitas dalam alur ceritanya (Setiawan, 2018), sehingga dirasa relevan diterapkan untuk membahas fenomena pertanian dan industry pertanian di Desa Celuk Buruan. Berhubungan dengan sinema, tentunya memiliki suatu struktur dalam sajian ceritanya, struktur tersebut membuat alur cerita dari film akan semakin kuat. Struktur cerita memiliki kemiripan dengan struktur perancangan, dari prolog, konflik hingga penutupnya dirangkai menjadi acuan cerita (Setiawan, Adnyana, Winatha, \& Trisemarawima, 2019).

Perancangan dokumenter ini berkaitan pula dengan motivasi dibalik alur ceritanya. Motivasi tersebut menurut Frence dan Reven adalah suatu yang mendorong seseorang untuk menunjukkan perilaku tertentu (Sule, Ernie Tisnawati \& Saefullah, 2006). Teori tersebut dilengkapi lagi oleh Hisbuan yang menganggap motivasi (motif) sering kali 
disamakan dengan dorongan. Dorongan atau tenaga tersebut merupakan gerak jiwa dan jasmani untuk berbuat, sehingga motif tersebut menggerakkan manusia untuk bertingkah laku dan perbuatan itu mempunyai tujuan tertentu. Pendapat tersebut didukung oleh Jones, mengatakan motivasi mempunyai kaitan dengan suatu proses yang membangun dan memelihara perilaku kearah suatu tujuan (Sutrisno, 2009). Wacana tentang motif dalam motivasi memiliki relevansi hubungan dibalik alur cerita dokumenter tentang pelestarian sektor pertanian di Celuk Buruan, oleh karenanya motivasi digunakan sebagai bagian dari perancangan.

\section{METODE PENELITIAN}

Dokumenter yang akan dirancang sepenuhnya menggunakan pendekatan kualitatif dengan komparasi berbagai kajian sumber dan landasan teori yang berkaitan. Dianalisis berdasarkan struktur model penelitian dengan data-data yang terkumpul di lapangan ysng sesuai dengan tujuan penelitian. Data diambil secara kolektif dalam studi lapangan (survei) dan studi pustaka untuk mendalami fenomena pada topik ini, sehingga data tersebut dapat disimpulkan dan dinarasikan dalam media dokumenter. Metode dilakukan secara kualitatif yakni peneliti sebagai instrumen penelitian dengan melakukan semua proses penelitian beserta analisisnya (Sugiyono, 2009). Metode analisis kualitatif didukung pendekatan interpretatif yakni mengulas tentang peristiwa sosial ataupun budaya berdasarkan perspektif suatu pengalaman ataupun organisasi. Pendekatan tersebut merupakan sebuah sistem sosial yang memaknai perilaku pada hasil observasi (Neuman, 1997). Faktor penting dari rancangan dokumenter yang akan dibahas adalah sebagai berikut:

a) Data langsung yang didapatkan dari olahan data primer dan data kepustakaan sebagai data sekunder. Data kepustakaan dikumpulkan berdasarkan sumber-sumber bacaan halnya buku, makalah seminar, majalah, koran dan sumber-sumber tertulis lainnya yang dianggap relevan dengan pendekatan landasan teori. Sedangkan sumber-sumber lainya dikumpulkan dari observasi lapangan dan wawancara dari narasumber terkait yakni para pelaku pertanian dan industrinya serta tokoh masyarakat yang berkompeten dalam bentuk dokumentasi audio-visual.

b) Pengumpulan sumber-sumber data dilakukan dengan pencarian secara porpusive sampling dan kemudian diinterpretasikan serta dinarasikan secara deskriptif komparatif.

Dokumenter ini pada sudut pandang penelitian kualitatif sumber datanya dari informan yang dikategorikan menjadi informan kunci dan informan pelengkap. Informan kunci adalah para pelaku sektor pertanian yakni para petani sekaligus sebagai anggota subak dan pelaku industri kecil pada sektor pertanian. Sedangkan informan pendukung adalah tokoh masyarakat yang berkompeten, memiliki wawasan pada sektor pertanian beserta industrinya pada kawasan setempat. Kedua kategori informan tersebut terfokus pada pertanian dan industri pertanian di Desa Celuk Buruan. 


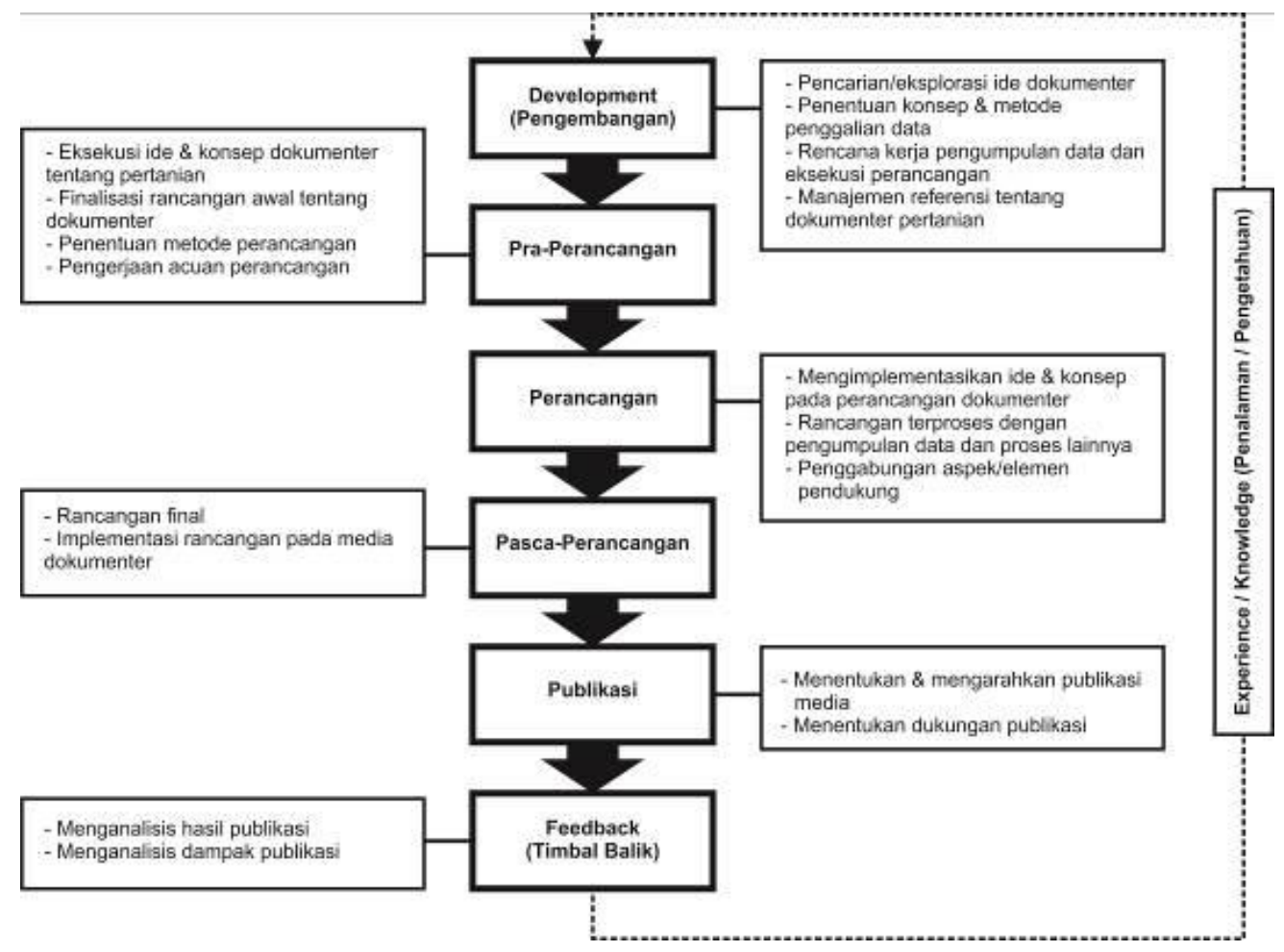

Gambar 1. Bagan proses perancangan dokumenter.

[Sumber: Data penulis]

Pada bagan proses perancangan (gambar 1) dapat dilihat dengan jelas bahwa tindakan yang perlu dilakukan dalam merancang memerlukan proses dan tahapan perencanaan dengan matang. Hal tersebut bertujuan agar tiap tahapan yang dilakukan dalam merancang dapat berjalan dengan baik dan meminimalkan segala resiko terkait proses saat perancangan dilaksanakan.

\section{HASIL DAN PEMBAHASAN}

\subsection{Sekilas Tentang Desa Celuk Buruan}

Desa Celuk merupakan salah satu dusun atau desa adat secara tradisional dalam admisnistratif berada pada wilayah Desa Dinas Buruan. Desa Buruan dalam bentuk administratif kedinasan dinaungi 7 desa adat diantaranya Desa Celuk, Desa Ketandan, Desa Kutri, Desa Buruan, Desa Bangunliman, Desa Getas Kangin, dan Desa Getas Kawan yang saling berkordinasi pada tingkat pemerintahan. Desa Celuk berbatasan langsung dengan beberapa desa yakni Desa Buruan (barat), Desa Marga Sengkala (utara), Desa Bitra (timur), dan Desa Getas (selatan) (Gianyar, n.d.). Berhubungan dengan sektor pertanian Bali, Desa Celuk mayoritas masyarakatnya bermatapencaharian sebagai petani. Desa ini memiliki suatu organisasi yang memanajemen pertanian tradisional setempat yang disebut Subak Celuk. Menurut data dari BPS Kabupaten Gianyar, secara global keberadaan lahan pertanian tahun 2016 (BPS, 2016) dan tahun 2019 (BPS, 2019) di kawasan kecamatan Blahbatuh (termasuk Desa Celuk di dalamnya) mengalami penurunan 1,5 persen. Namun pada kenyataannya rentang waktu 5 tahun terakhir telah terjadi banyak perubahan terutama pada alih fungsi lahan-lahan produktif untuk pertanian. Hal inilah kemudian menjadi konsep dasar dalam perancangan dokumenter 
yang bertujuan membuka fenomena dan pemikiran untuk menggairahkan kembali sektor pertanian, terutama pada wilayah desa sebagai salah satu tulang punggung perekonomian.

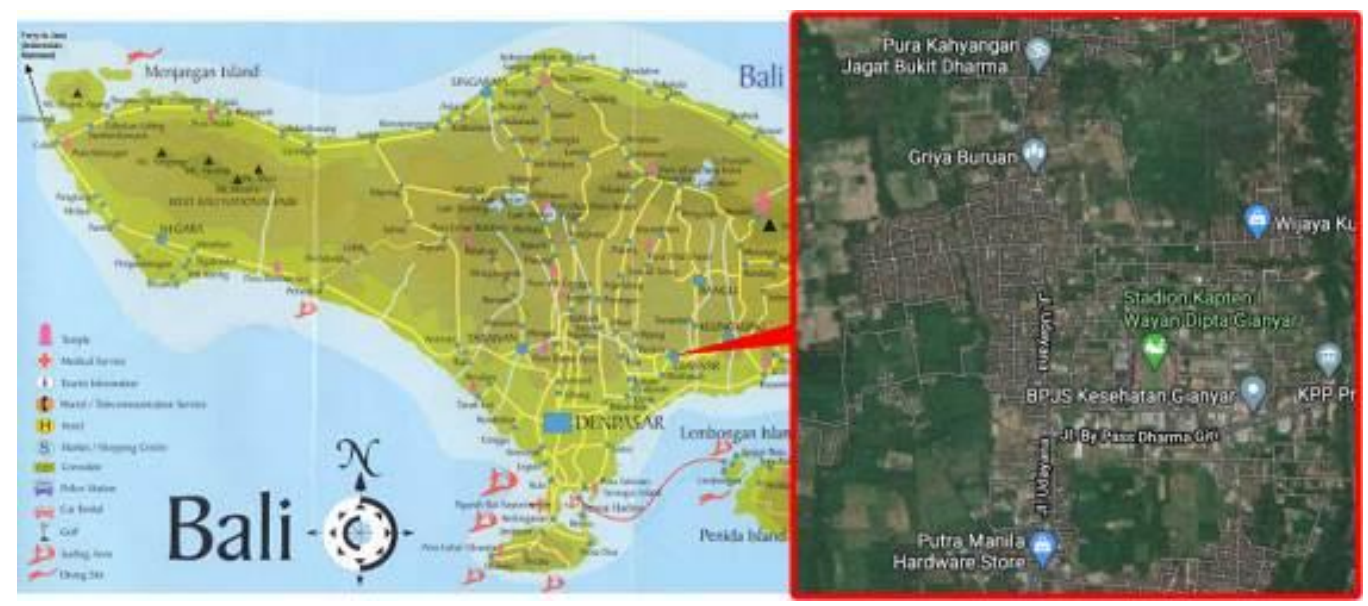

Gambar 2. Wilayah Desa Celuk dalam administrasi kedinasan Desa Buruan.

[Sumber: google map]

\subsection{Organisasi Tradisional Subak di Celuk Buruan}

Pertanian Bali memiliki sistem organisasi tradisional untuk sistem manajemen lahan pertanian dan perkebunan sebagai bagian kearifan lokal budaya agraris yaitu subak. Hal yang sama dimiliki pula oleh pertanian di Desa Celuk Buruan dan desa-desa lainnya di Bali pada lahan-lahan di tiap-tiap daerah yang diterapkan atau dikelola anggota subak. Subak adalah lembaga tradisional sosio-agraris religius atau organisasi tradisional masyarakat dalam tatanan religi masyarakatnya (Suryawan, 2018). Subak secara umum terdiri dari dua jenis yaitu subak abian (perkebunan) dan subak yeh (persawahan) dan di Desa Celuk Buruan mayoritas anggotanya masuk dalam kategori subak yeh. Subak dapat dipahami pula sebagai organisasi yang mengatur sistem pertanian dan perkebunan halnya irigasi, waktu dan durasi tanam, penyaluran atau pembagian pupuk, manajemen panen raya, dan sebagainya. Subak di Bali sangat terasa nuansa religinya terutama berbagai hal yang berhubungan antara aktifitas tani, adat istiadat, dan berkeTuhanan. Oleh karenanya, organisasi subak yang sudah ada sejak dulu dan dijalani dari generasi ke generasi, kini telah menjadi bagian dari warisan budaya dunia (Kebudayaan, n.d.).

Berkaitan dengan wacana tentang subak, di Celuk Buruan hanya memberlakukan satu sistem subak saja yaitu subak yeh dengan sistem pertanian lahan basah. Penerapan subak yeh dalam organisasi subak di Celuk Buruan dikarenakan kawasan tersebut mayoritas lahan lebih cocok untuk pertanian lahan basah dan pengairan sistem irigasi yang melimpah. Sistem organisasi ini pula diterapkan pada enam desa lainnya di Desa dinas Buruan yang merujuk arah pengairan untuk irigasi hulu dan hilir memiliki jalur yang sama dan dapat dimanfaatkan untuk mengairi lahan pertanian oleh petani setempat. 


\subsection{Data Sebaran Informan}

Pengumpulan data dari informan tersebar di beberapa tempat yaitu berlokasi pada rumah kediaman dari anggota subak dan kelihan atau ketua subak Celuk sebagai pelaku yang menghadapi secara langsung dengan fenomena yang terjadi. Pelaku industri kecil sektor pertanian pada usaha penyosohan gabah yang tertua di Kecamatan Blahbatuh sebagai yang terdapak dalam sektor ekonomi pertanian. Tokoh masyarakat Desa Celuk yang memahami tentang pertanian secara tradisional dan modern. Khusus untuk petani, data diambil berdasarkan hulu sampai hilir berdasarkan jalur irigasi dari wilayah subak Celuk sampai ke wilayah subak Getas. Lokasi tersebut berjarak berdekatan satu sama lain dan masih dalam lingkup wilayah Desa Dinas Buruan. Sebaran lokasi informan sebagai sumber data dapat dilihat pada gambar 2 agar dapat tergambar keadaan kondisi lingkungan dan situasi lapangan yang dimaksud.

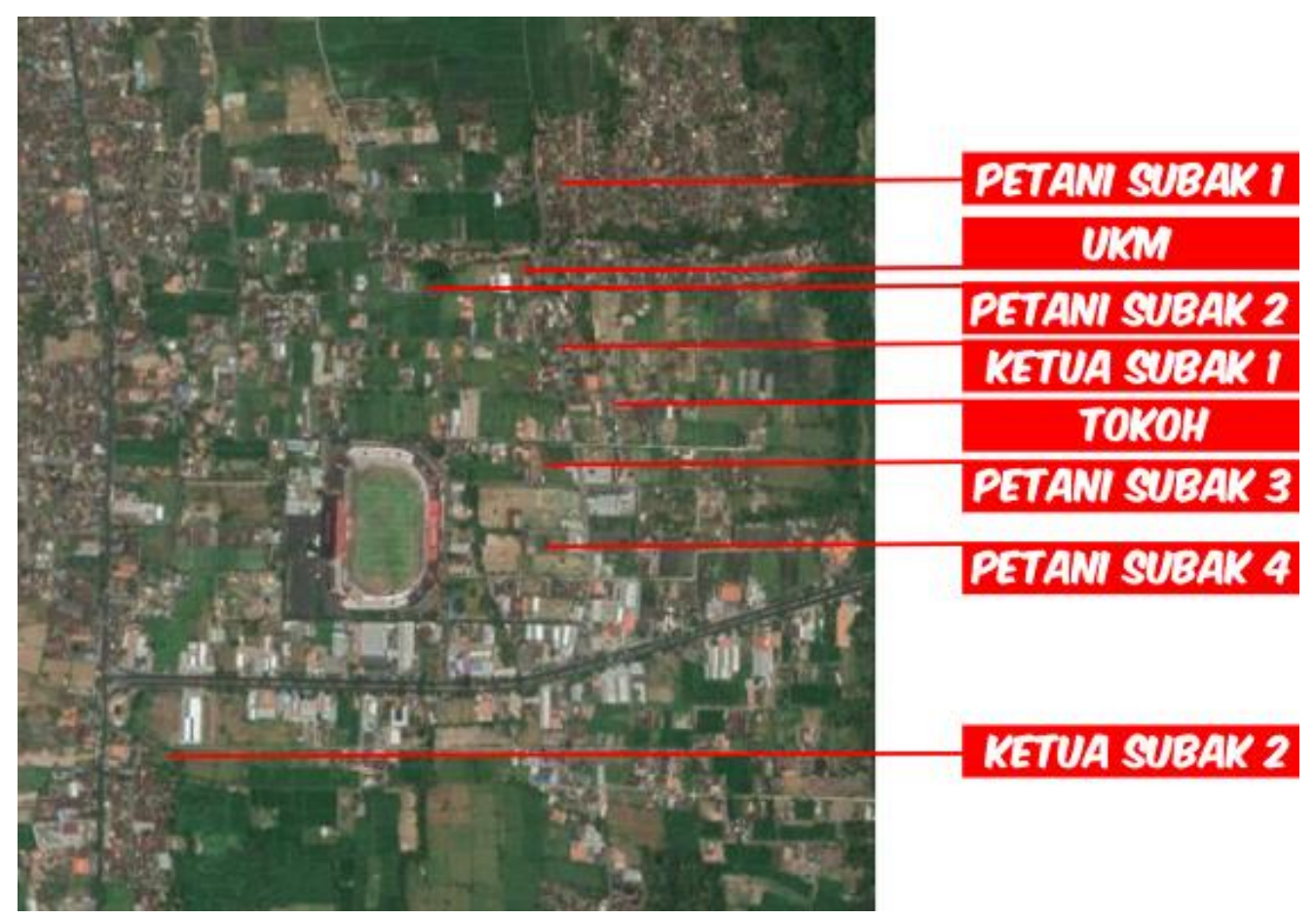

Gambar 3. Pemetaan sebaran lokasi penggalian data.

[Sumber: Google Map dan data penelitian]

Pada gambar 3 terlihat sebaran lokasi pada kawasan di Desa Dinas Buruan mengikuti jalur irigasi berdasarkan penginderaan Google Map dapat menjelaskan pula gambaran umum tentang lokasi diantaranya a) Petani 1 sekaligus anggota subak Buruan I Ketut Genda, b) Pelaku Usaha yang membantu petani dalam penyosohan hasil pertanian I Nyoman Gde Setiawan, c) Petani 2 sekaligus anggota subak Celuk I Ketut Mustika, d) Ketua subak 1 Celuk sekaligus petani I Gusti Ngurah Wirayudha, e) Ketua subak 2 sekaligus petani Getas I Made Tingen, f) Tokoh masyarakat yang berkompeten pada bidang pertanian dan perkebunan Made Putra Suryawan, g) Petani 3 sekaligus anggota subak Buruan dan Celuk I Wayan Pugra, h) Petani 4 sekaligus anggota subak Celuk I Made Wirawan. 
Sedangkan pengambilan gambar sekaligus dokumentasi terdapat di beberapa tempat penting sebagai kunci serta pendukung sebagai variatif visual (gambar 3) diantaranya a) pada lahan persawahan subak Celuk, b) pada lahan persawahan subak Buruan, c) pada lahan persawahan subak getas, d) pada pelatara Pura Gunung Sari Dusun Celuk, e) pada kawasan saluran irigasi subak Celuk, f) pada kawasan aliran sungai yang mengaliri kawasan hilir Kecamatan Blahbatuh, g) kawasan pemukiman ditengah lahan persawahan Celuk, h) tempat usaha penyosohan gabah tertua di Kecamatan Blahbatuh, i) pada kediaman tokoh masyarakat terkait pertanian, j) kediaman para petani di Desa Celuk, Desa Buruan, Desa Getas, k) Stadion Kapten I Wayan Dipta, I) ruas jalan By Pass Dharma Giri.

\subsection{Data Informan dan Kriterianya}

Berdasarkan pengumpulan data, hal-hal yang penting dilakukan bertujuan untuk mempersiapkan dokumentasi yang lebih terencana dan terarah saat penyajian dalam alur cerita dokumenter. Pengumpulan data juga terkait dengan jabaran yang dijelaskan pada pemetaan gambar 3 yang dilakukan bertahap dan dikomparasikan dengan data primer lainnya. Pada hasil data dan informasi yang didapatkan, kemudian berkembang pada pemetaan proses persiapan pengambilan gambar pada hari yang telah disepakati dengan para informan di lapangan.

Wawancara awal dilakukan kepada para petani yang telah ditargetkan yaitu I Made Wirawan, I Ketut Genda, dan I Wayan Pugra berkaitan dengan lahan produktif desa, irigasi, kebutuhan petani dan ketersediaan kebutuhan pertanian. Pada wawancara tersebut dapat dirangkum bahwa irigasi pada kawasan subak Celuk dan Buruan secara umum tidak ada permasalahan. Namun dua tahun terakhir mengalami sedikit permasalahan yang dikarenakan ada proses pengeringan jalur irigasi karena perbaikan bendungan pada hulu, dan debit air yang berlebihan saat musim penghujan yang dikarenakan jalur irigasi yang terganggu oleh pemukiman. Kendala lain adalah fluktuasi harga yang selalu berubah namun kebutuhan pupuk dan perlengkapan pertanian yang semakin mahal menyebabkan dari sisi keuntungan hasil panen menjadi sangat tipis. Munculnya kendala ini bagi petani bukanlah hal yang sederhana dan membutuhkan kerja lebih keras dalam mengolah lahan agar tetap produktif tanpa harus menjual lahan mereka. Dikatakan pula, alih fungsi lahan dari pertanian menjadi pemukiman, perkantoran dan ditambah dengan adanya akses jalan By Pass Dharma Giri dan Stadion Kapten Dipta, merubah pikiran petani untuk menjual lahan mereka karena terkait olah lahan yang banyak kendala dan hasil panen yang tidak menentu.

Pada sisi organisasi subak, mewawancarai dua orang yaitu I Gusti Ngurah Wirayudha dan I Made Tingen, selain sebagai petani, informan ini merupakan ketua subak di Celuk dan Getas serta mengurus para petani, lahan, beserta kebutuhannya dibawah organisasi tradisional tersebut. Secara umum dua kawasan ini mengalami banyak alih fungsi lahan sehingga otomasis berkurang juga anggota subak karena pemilik lahan tidak memiliki lahan karena telah dijual. Penjualan lahan begitu terasa setelah dibangunnya fasilitas jalan dan stadion di kawasan Desa Buruan dan merubah lahan produktif petani menjadi lahan strategis yang bernilai jual tinggi. Namun hal tersebut tidak hanya mengancam 
arah irigasi dan lahan produktif saja tetapi juga mengancam keberlangsungan subak yang kini anggotanya semakin berkurang. Perbedaan antara kawasan subak Celuk dan Getas, kawasan celuk terjadi alih fungsi lahan yang cukup tinggi sehingga lahan produktif semakin sempit.

Wawancara lainnya pada I Ketut Mustika sebagai petani dan anggota subak Celuk yang menjelaskan pengairan pada irigasi di subak Celuk. Kawasan Celuk memiliki aliran sungai bertingkat tiga menuju tiga daerah dan mengairi lahan pada daerah yang dilaluinya. Aliran tersebut selain mengairi sawah yang terdapat di subak Celuk, juga mengairi setengah dari kawasan Kecamatan Blahbatuh. Selain itu tiap organisasi subak pada tiap daerah dan kawasan yang dialiri oleh sungai-sungai tersebut wajib memelihara lingkungan sungai.

Pada sisi lain dari sudut pandang pengusaha kecil oleh Bapak I Nyoman Gde Setiawan, pengelola penyosohan gabah dan salah satu yang tertua di Kecamatan Blahbatuh yang dinamakan Penyosohan Gabah Sri Wedhari. Walaupun sebagai usaha kecil, namun perusahaan ini selalu taat dalam membayar pajak dan transaksi yang ada tidak menggunakan uang secara fisik. Transaksi yang terjadi menggunakan pertukaran jasa dan barang yaitu gabah yang disosoh menjadi beras dengan persentase tertentu. Praktek ini telah dijalani dua generasi sejak tahun 1971, dan pendiriannya karena keprihatinan orang tua pemilik terhadap keadaan dan membantu petani dengan kepemilikan lahan panen terbatas. Selain itu penyosohan ini berada dekat dengan lahan petani sehingga tidak membutuhkan biaya transportasi untuk pengangkutan hasil panen jika akan disosoh. Hal menarik lainnya adalah berkaitan dengan hasil keuntungan yang tidak dinikmati seluruhnya, sebagian hasil disumbangkan kembali ke desa jika terdapat upacara besar pada tempat suci setempat setiap enam bulan sekali. Namun kini keberadaan usaha ini menjadi semakin sulit karena dampak berkurangnya hasil panen, bahkan sekedar agar usaha ini tetap berjalan.

Wawancara kunci lainnya adalah pada Made Putra Suryawan selaku tokoh masyarakat yang sangat memahami dan mempelajari sektor pertanian dan teknologinya. Informan mengatakan bahwa telah tersedia piranti hukum prihal perlindungan lahan pertanian, namun kenyataannya sangat berbeda dengan apa yang terjadi di lapangan. Hal ini harus pula mengikut sertakan generasi muda dalam merubah sudur pandang pertanian yang selama ini dipandang sebelah mata. Pertanian lahan produktif dengan pengelolaan yang baik dan didukung investor yang sehat justru akan memberikan keutungan lebih baik dari pada harus menjual lahan. Pertanian organik juga hasil panennya sangat diincar konsumen terutama ekspatriat, namun usaha dari petani juga harus mendapatkan edukasi yang seimbang dengan hal tersebut.

\subsection{Analisis Data Kolektif}

Berdasarkan pengumpulan data primer, dapat ditarik analisis sebagai penentuan arah alur cerita pada rancangan dokumenter nantinya. Selain itu, analisis tersebut dapat menjadi acuan dokumentasi dalam menyusun tiap scene dalam struktur dokumenter dan memilah secara runut kronologi kejadian berdasarkan fakta tentang fenomena yang 
terjadi pada pertanian dan industri pertanian Celuk Buruan. Bila dijabarkan secara umum, poin-poin tersebut adalah sebagai berikut:

a) Perspektif petani menjabarkan tentang lahan produktif yang masih mereka pertahankan sampai saat ini serta aktifitas pertanian dan kebutuhannya yang kian meningkat dari persaingan harga. Hal lainnya dampak alih fungsi yang berpengaruh pada lahan-lahan produktif para petani.

b) Perspektif subak yang mengangkat sisi keberadaan organisasi dan lahan yang diaturnya, juga manajemen tradisional yang terdapat pada misi dari subak itu sendiri yang berkaitan dengan tradisi Bali. Dampak alih fungsi pula akan diangkat terutama ancaman akan keberlangsungan tradisi dalam manajemen subak dan masa depannya di Bali.

c) Perspektif irigasi, selain memiliki fungsi pengairan, perawatan dan pelestarian lingkungan juga berperan dalam implementasinya terutama dalam aktifitas kewajiban anggota subak.

d) Perspektif pengusaha kecil menjabarkan keberlangsungan usaha yang kian hari semakin sulit karena dampak alih fungsi yang terjadi terhadap hasil panen rakyat. Penurunan penghasilan juga mempersulit keberlangsungan usaha sinerginya membantu para petani.

e) Perspektif tokoh masyarakat menjabarkan tentang pentingnya untuk kembali mempertimbangkan pelestarian pertanian dengan cara mengedukasi para petani, pelaku usaha, dan generasi muda. Hal ini bertujuan agar masyarakat pada komponen ini dapat mempertahankan perekonomian lokal melalui sektor pertanian.

\subsection{Struktur Rancangan Dokumenter}

Berdasarkan proses yang muncul dalam analisis dari hasil komparasi data primer dan sekunder maka dapat pula dijelaskan alur cerita yang akan dirancang dalam dokumenter. Berikutnya pula kebutuhan alat dan perlengkapan lainnya dalam melakukan dokumentasi untuk merekam semua fakta-fakta lapangan yang kemudian disusun menjadi cerita secara naratif dalam dokumenter. Pada kebutuhan peralatan, secara garis besar meliputi kamera rekam video profesional, alat bantu pencahayaan, peralatan pendukung proses editing, software, hardware, dan peralatan lainnya yang mendukung pembuatan dokumenter ini dan secara arah struktur cerita dijabarkan sebagai berikutnya pada gambar 4 .

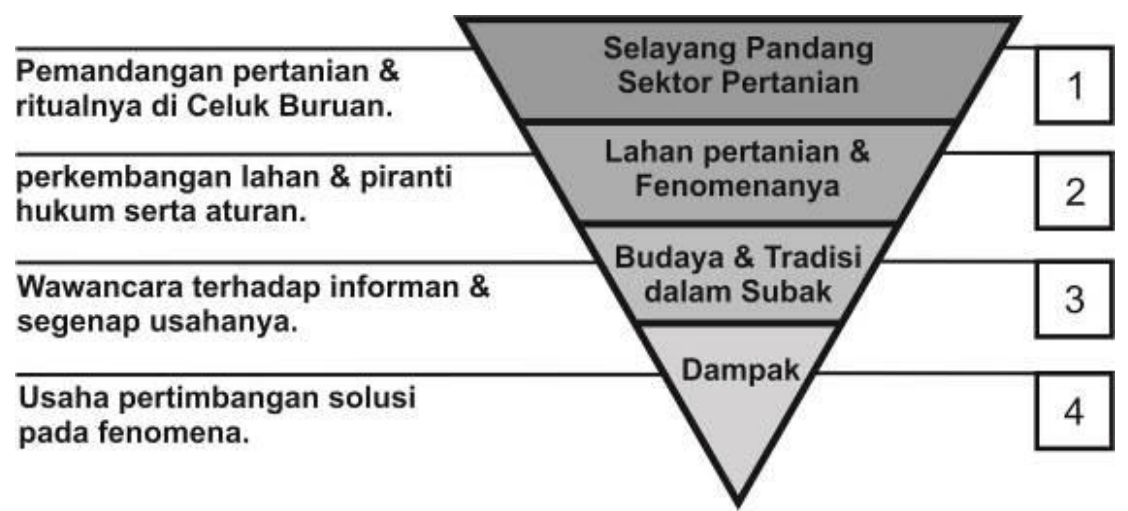

Gambar 4. Struktur perancangan dokumenter.

[Sumber: Data penulis] 


\subsection{Pra Perancangan}

Adanya runut analisis dan stuktur perancangan, maka narasi yang akan disajikan dapat dipersiapkan bersama dengan elemen penting lain dalam perancangan. Pra perancangan yang dimaksud adalah pra proses, dengan dokumen yang berhubungan pada kebutuhan dokumenter. Kebutuhan tersebut seperti panduan atau acuan dalam proses mendokumentasi keadaan, sajian fakta, teknik pengambilan gambar dan sebagainya yang diperlukan sebelum atau dalam perjalanan proses. Tahap persiapan awal memerlukan dua elemen yakni mempersiapkan script atau skenario yang berupa struktur teks rancangan plot cerita dokumenter. Pada persiapkan berikutnya storyboard atau papan penceritaan sebagai acuan pandu pengambilan gambar beserta ragam rencana teknik yang akan digunakan. Segala bentuk persiapan sangat penting untuk dasar tindakan yang terencana dilapangan, sehingga proses yang akan dijalani dalam perancangan dokumenter pertanian dan industri pertanian di Celuk Buruan menjadi lebih efektif dan efisien sesuai perencanaan awal. Sajian script dan sekaligus storyboard secara umum telah tersirat pada pembahasan sebelumnya untuk menyikapi keterbatasan halaman pada manuscript.

\begin{tabular}{|c|c|c|c|}
\hline \multicolumn{4}{|c|}{ SHOT \# } \\
\hline Sketch & Image Description & Audio & Notes \\
\hline & $\begin{array}{l}\text { Camera: trackin slow } \\
\text { aktfitas petani }\end{array}$ & BG: Eurika & rules of third \\
\hline \multicolumn{4}{|c|}{ SHOT \# 81} \\
\hline Sketch & Image Description & Audio & Notes \\
\hline & $\begin{array}{l}\text { Camera: stil } \\
\text { wawancara petani } 1\end{array}$ & BG: Eurika & rules of third \\
\hline \multicolumn{4}{|c|}{ SHOT \# 82} \\
\hline Sketch & Image Description & Audio & Notes \\
\hline & $\begin{array}{l}\text { Camera: follow } \\
\text { petani berjalan di pema- } \\
\text { tang sawah }\end{array}$ & BG: Eurika & $10 \%$ slow motion \\
\hline
\end{tabular}

Gambar 5. Sekilas tampilan storyboard.

[Sumber: Dokumentasi penulis]

\subsection{Perancangan}

Proses perancangan merupakan kelanjutan aksi setelah adanya pra perancangan pada ulasan sebelumnya. Perancangan merupakan aksi utama dokumenter ini akan direalisasikan melalui proses video editing dengan acuan segala yang telah dipersiapkan 
dalam rencana pra perancangan. Hal yang sangat menyulitkan dan perlu diperhatikan dalam dokumenter adalah momen-momen yang tidak dapat diulangi kembali. Reka adegan belum tentu akan memberikan kesan naturalitas dalam sebuah tayangan dokumenter, apalagi berhadapan dengan informan yang sama sekali tidak memiliki pengalaman akting. Oleh karena itu, maka tim dan peralatan yang membatu pengambilan gambar (walau dalam situasi peralatan yang terbatas) harus dikuasai dan perlu ketelitian dalam pengambilan tiap frame-nya.

Pendekatan ke informan sebagai narasumber dalam hal ini perlu sangat persuasif agar tidak terfokus pada lensa kamera dan membuat suasana senatural mungkin untuk mengurangi kepercayaan diri narasumber. Sudut yang diambil setidaknya menggunakan lebih dari satu sudut pandang, pencahayaan, mengambil tiap momen tanpa henti untuk dipilah berikutnya pada saat editing dilakukan. Pengarah gaya sering kali tidak berlaku pada situasi ini, selain alasan yang telah disebut dikarenakan pula pentingnya suasana nyaman dikedepankan. Faktor penggalian informasi lebih penting dan perlu strategi khusus dilakukan agar informasi yang diperlukan keluar dan mengalir sepenuhnya dari narasumber. Setelah perekaman gambar dan suara dapat dilaksanakan, sesuai dengan acuan, dan informasi telah didapatkan maka akan melangkah pada proses selanjutnya yaitu pasca perancangan yang akan dijabarkan pada sub selanjutnya.

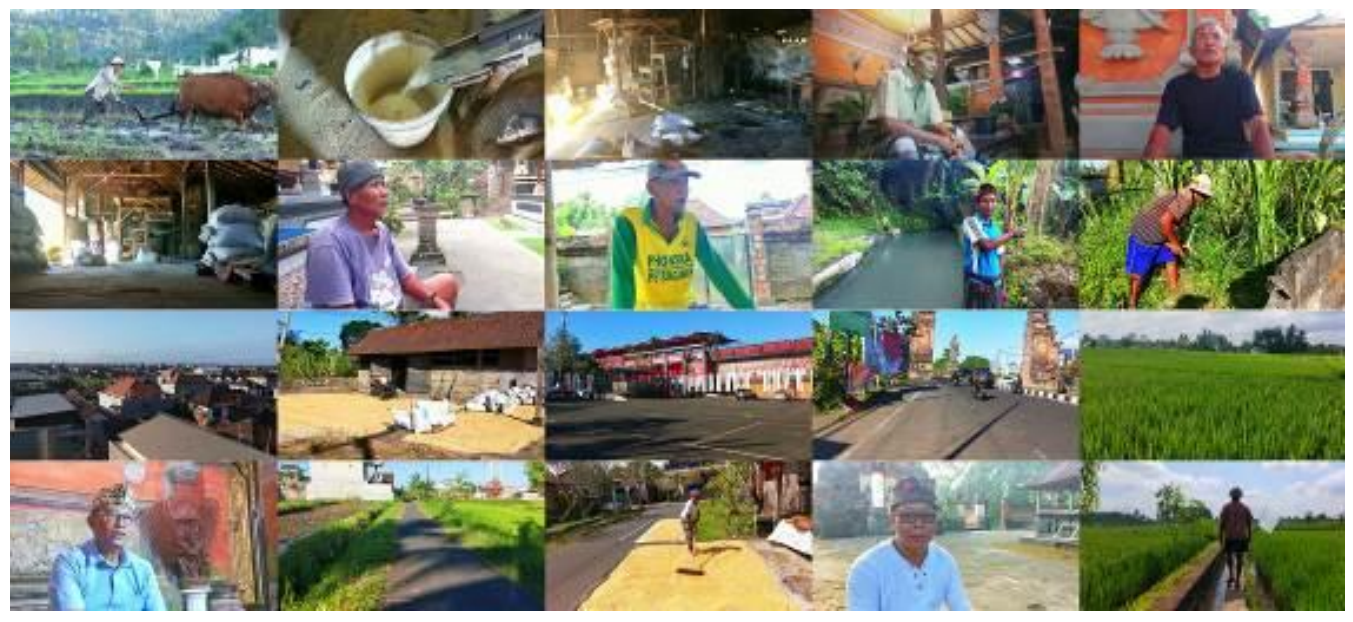

Gambar 6. Beberapa hasil pengambilan gambar di lapangan mengikuti storyboard.

[Sumber: Dokumentasi penulis]

\subsection{Pasca Perancangan}

Tahapan selanjutnya adalah pasca perancangan, secara umum semua gambar video dan audio dipilah serta disesuaikan dengan tren dalam alur cerita dokumenter. Pada proses ini, acuan skenario dan gambar penceritaan masih tetap digunakan dalam penggabungan antara dokumentasi (dalam bentuk audio dan video) dan penyesuaian dengan alur cerita yang dikehendaki dalam dokumenter. Proses compositing dilakukan dengan bantuan hardware dan software yang sesuai karena berhubungan dengan durasi proses editing dan rendering hasil akhir nantinya. 


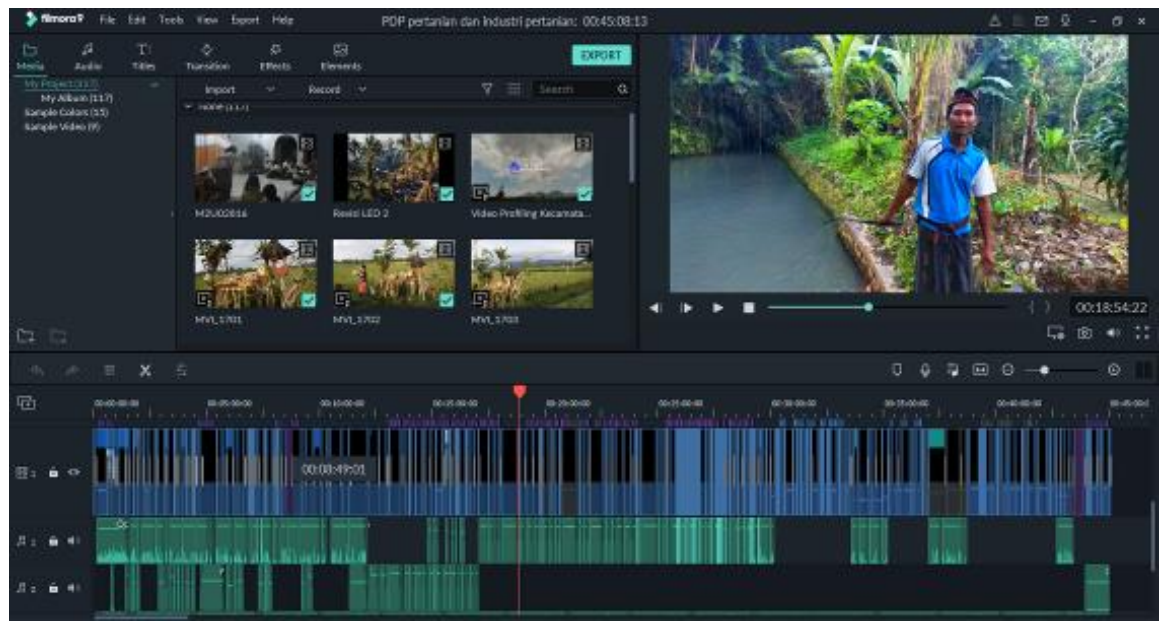

Gambar 7. Proses compositing pada aplikasi video editing.

[Sumber: Dokumentasi penulis]

Adapun terkait kualitas dari hasil video dengan luaran aspec rasio 16 : 9; encoder H.264; Kualitas video HD quality berresolusi 1920 x 1080 px; frame rate 29,97 fps; bit rate $10.000 \mathrm{kbps}$; dan audio dengan luaran encoder AAC; channel stereo; sample rate 44100 $\mathrm{Hz}$; bit rate $192 \mathrm{kbps}$. Sedangkan luaran secara keseluruhan pada video dengan durasi full video total 45 menit 8,13 detik berformat MP4 dan 1 menit berformat MP4 untuk tayangan trailer.

\subsection{Publikasi}

Pada aspek publikasi, dokumenter ini akan disebarluaskan melalui perantara media sosial youtube.com yang dapat diakses dengan mudah pada tautan full video https://www.youtube.com/watch?v=raxZ7QMI4Eg\& $t=54 \mathrm{~s}$ dan tautan trailer pada https://www.youtube.com/watch?v=xvQxaQqR7Ig. Penayangan melalui media sosial ini dengan pertimbangan dapat menggapai lebih luas audiens dan dapat dinikmati setiap saat secara gratis dalam penyebarluasan misi sosialnya.

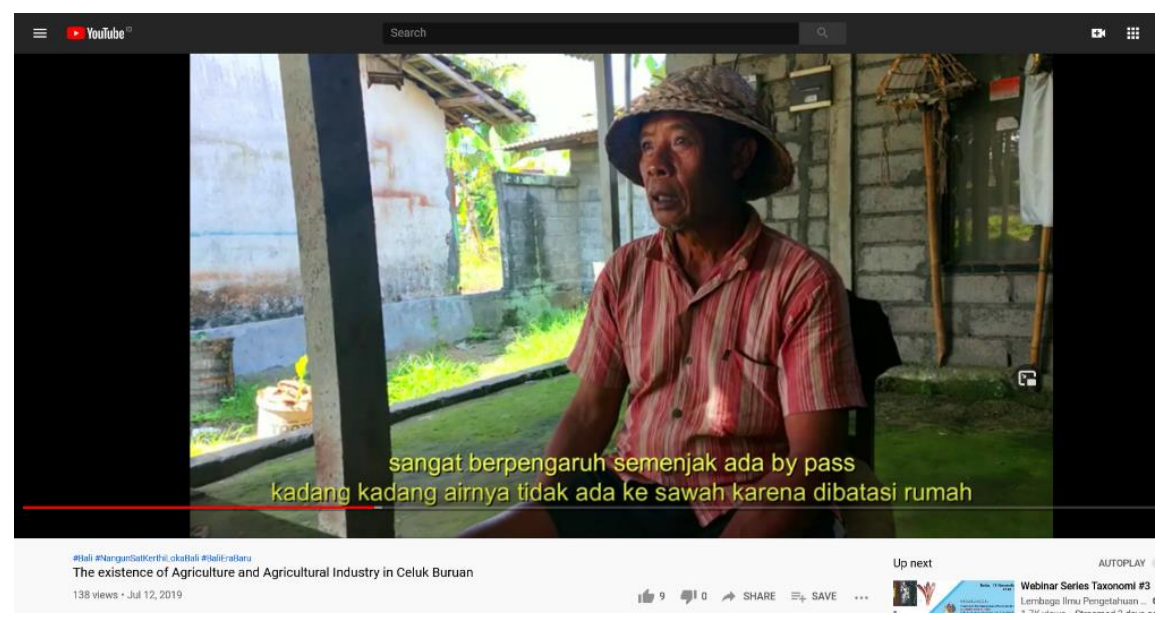

Gambar 8. Screenshot penayangan di youtube

[Sumber: dokumentasi penulis] 


\section{KESIMPULAN}

Berdasarkan proses yang telah dilakukan dalam merancang dokumenter, dapat dirumuskan beberapa poin kesimpulan yaitu perancangan sebuah dokumenter tentang pertanian dan industri pertanian, dilakukan berdasarkan proses yang terstruktur dan terencana sehingga hasil luaran yang ingin dicapai dapat maksimal. Selain itu, diperlukan suatu pendekatan riset dan pendekatan kultural terutama pada lini-lini tertentu untuk mendapatkan informasi yang lebih mendalam. Lini tersebut misalnya saat berhadapan dengan para petani, pelaku usaha, atau tokoh masyarakat sebagai informan dengan tingkat edukasi yang berbeda-beda, menggali berbagai informasi terkait alih fungsi yang terjadi di Desa Celuk Buruan utamanya untuk pengambilan gambar yang mewakili alur cerita agar semakin kuat mengangkat fenomena yang terjadi. Pada lingkup perancangan dokumenter, penerapan struktur cerita perlu perencanaan yang matang walaupun dokumenter tersebut berbasis fenomena. Luaran akhir dari dokumenter, mempertimbangkan media publikasinya agar kualitas penayangan dapat disajikan dengan maksimal dalam resolusi yang sepadan.

Pada analisis secara umum, ternyata memunculkan indikasi lain yaitu munculnya motivasi dalam alur cerita dan pada alur proses perancangan dalam membangun suatu dokumenter tentang sektor pertanian. Perlu pengkajian ulang terkait data statistik dari acuan data dan kenyataan di lapangan, khususnya terkait dengan data lahan sawah produktif pada rentang waktu tertentu. Berkaitan dengan sektor pertanian dan beragam hubungan dalam lingkupnya, prihal hasil dari lahan produktif petani menjadi sangat penting untuk dipertimbangkan keberadaanya terutama seperti keadaan pada saat ini atau jika suatu wilayah terdampak bencana ataupun wabah. Sehingga sektor pertanian menjadi salah satu garda terdepan sebagai solusi permasalahan pangan pada situasi tersebut.

\section{DAFTAR PUSTAKA}

Binanto, I. (2010). Multimedia Digital - Dasar Teori dan Pengembangannya. C.V Andi Offset. Yogyakarta: Andi.

BPS. (2016). Kecamatan Blahbatuh dalam Angka 2016. Gianyar: Badan Pusat Statistik Kabupaten Gianyar.

BPS. (2019). Kecamatan Blahbatuh dalam Angka 2019. Gianyar: Badan Pusat Statistik Kabupaten Gianyar.

Gianyar, K. (n.d.). Situs Resmi Pemerintah Kabupaten Gianyar. Retrieved April 20, 2020, from https://www.gianyarkab.go.id/perangkat_daerah/19/Kecamatan.html

Kebudayaan, K. P. dan K. (n.d.). Subak Sebagai Warisan Dunia. Retrieved March 30, 2020, from https://kebudayaan.kemdikbud.go.id/subak-sebagai-warisan-dunia-2/

Metrobali.com. (n.d.). Sektor Pertanian Diharapakan Berperan Dalam Pelestarian Lingkungan, Adat dan Budaya Bali. Retrieved April 18, 2020, from http://metrobali.com/sektor-pertanian-diharapakan-berperan-dalampelestarian-lingkungan-adat-dan-budaya-bali/

Neuman, W. L. (1997). Social Research Methods Qualitative and Quantitative Approache. Boston: Allyn \& Bacon. 
Setiawan, I. N. A. F. (2018). Sinema Paradoks : Pengantar dan Konteks Kontemporer. (I. N. Jayanegara, Ed.). Denpasar: STMIK STIKOM Indonesia.

Setiawan, I. N. A. F., Adnyana, I. N. W., Winatha, K. R., \& Trisemarawima, I. N. Y. (2019). Film Dokumenter Eksistensi Tarian dan Kesenian Sakral Wayang Wong Desa Adat Sidan. ANDHARUPA: Jurnal Desain Komunikasi Visual \& Multimedia, 5(2), 251-264.

Sugiyono. (2009). Metode Penelitian Kuantitatif, Kualitatif dan R\&D. Bandung: Alfabeta. Sule, Ernie Tisnawati \& Saefullah, K. (2006). Pengantar Manajemen. Jakarta: Prenada Media.

Suryawan, M. P. (2018). Perlindungan Lahan Pertanian Pangan Berkelanjutan dalam Mendukung Pelestarian Subak. Bali Membangun Bali, 1(2), 145-152.

Sutrisno, E. (2009). Manajemen Sumber Daya Manusia Edisi pertama. Jakarta: Kencana Prenada Media Group. 